\title{
Metal removal from soil leachates using DTPA-functionalised maghemite nanoparticles, a potential soil washing technology
}

Article

Accepted Version

Creative Commons: Attribution-Noncommercial-No Derivative Works 4.0

Hughes, D. L., Afsar, A., Laventine, D. M., Shaw, E. J., Harwood, L. M. and Hodson, M. E. (2018) Metal removal from soil leachates using DTPA-functionalised maghemite nanoparticles, a potential soil washing technology. Chemosphere, 209. pp. 480-488. ISSN 1879-1298 doi: https://doi.org/10.1016/j.chemosphere.2018.06.121 Available at https://centaur.reading.ac.uk/78056/

It is advisable to refer to the publisher's version if you intend to cite from the work. See Guidance on citing.

To link to this article DOI: http://dx.doi.org/10.1016/j.chemosphere.2018.06.121

Publisher: Elsevier

All outputs in CentAUR are protected by Intellectual Property Rights law, including copyright law. Copyright and IPR is retained by the creators or other copyright holders. Terms and conditions for use of this material are defined in the End User Agreement. 


\section{www.reading.ac.uk/centaur}

\section{CentAUR}

Central Archive at the University of Reading

Reading's research outputs online 
Metal removal from soil leachates using DTPA-functionalised maghemite nanoparticles, a potential soil washing technology

Hughes, D.L. ${ }^{a 1}$, Afsar, A. ${ }^{b}$, Laventine D.M. ${ }^{b}$, Shaw, E.Ja., Harwood, L.M. ${ }^{b}$ and Hodson, M.E. $a, c$

aSoil Research Centre, Department of Geography and Environmental Science, School of Archaeology, Geography and Environmental Science, University of Reading, Whiteknights, Reading, RG6 6DW, UK.

bDepartment of Chemistry, University of Reading, Whiteknights, Reading, RG6 6AD, UK. 'Environment Department, University of York, YO10 5DD York, UK

Email: mark.hodson@york.ac.uk

\section{Abstract}

There is significant current interest in the application of magnetic (magnetite or maghemite) nanoparticles functionalised with chelating agents for the environmental remediation of metal contaminated waters and solutions. Whilst there is a body of knowledge about the potential remediation efficacy of such engineered nanoparticles from studies involving synthetic solutions of single metals, there is relatively little data involving mixed-metal solutions and virtually no studies about nanoparticle performance in chemically complex environmental solutions representing those to which a scaled-up nanoremediation process might eventually be applied. Therefore, we investigated the ability of diethylenetriaminepentaacetic acid (DTPA)-functionalised, silica-coated maghemite nanoparticles to extract potentially toxic (Cd, $\mathrm{Co}, \mathrm{Cu}$ ) and "non-toxic" ( $\mathrm{Ca}, \mathrm{Mg}$ ) metals from solution (initial [metal] $=10 \mathrm{mg} \mathrm{L}^{-1} ; \mathrm{pH}$ range: 2-8) and to extract a wider range of elements (As, $\mathrm{Ca}, \mathrm{Cd}, \mathrm{Co}, \mathrm{Cr}, \mathrm{Cu}, \mathrm{Mg}, \mathrm{Na}, \mathrm{Pb}, \mathrm{Zn}$ ) from leachate obtained from 10 different contaminated soils with variable initial $\mathrm{pH}$, (semi-)metal

\footnotetext{
${ }^{1}$ Current address: Thames Water Utilities Ltd, Spencer House, Manor Farm Road, Reading, RG2 OJN, UK
} 
and dissolved organic carbon (DOC) concentrations. The functionalised nanoparticles could extract the potentially toxic metals with high efficiency (in general $>70 \%$ ) from single metal solutions and with efficiencies that were either unaffected or reduced from the soil leachates. $\mathrm{K}_{d}$ values remained high (> $500 \mathrm{~L} \mathrm{~kg}^{-1}$ ), even for the soil leachate extractions. Our findings show that DOC and relatively high concentrations of non-toxic elements do not necessarily reduce the efficiency of metal contaminant removal by DTPA-functionalised magnetic nanoparticles and thus demonstrate the potential of this process when applied to chemically complex soil-derived contaminated solutions.

Keywords: metals; soil; DTPA; adsorption; remediation; nanoparticles

\section{Introduction}

The contamination of soils with toxic metals can potentially lead to significant health effects in humans, flora and fauna (Siegel, 2002). This occurs if a pathway of exposure to toxic metals is established. Toxic metals are present in many different phases in the soil including being bound to organic matter, iron or manganese hydroxides and being incorporated within the structure of mineral grains (Sahuquillo et al. 1999; Lei et al. 2010). However the most important fraction with regards to potential risk is the water soluble fraction as the metals within this fraction are both mobile and bioavailable (Seguin et al. 2004). This means they can be taken up by organisms and leach into rivers, lakes and groundwater thereby providing a pathway for plant, animal and human exposure. When metal contamination of soils poses a risk to the surrounding ecosystem and human health, remediation schemes are often instigated. Soil washing is an established technology used for removing toxic metals from soils, and aminocarboxylate chelating agents such as DTPA and EDTA are often used to enhance metal removal (Lestan et al., 2008). Whilst using chelating agents improves the effectiveness of metal removal, the techniques currently used for removing the chelating agents from solution after use, such as membrane separation, electrochemical treatment or precipitation via the addition of ferric chloride or calcium hydroxide can often 
add to remediation costs as they require inputs of energy or chemical reagents (Lo and Zhang, 2005; Finzgar and Lestan, 2008; Pochieca and Lestan, 2009).

The nanoparticle revolution has impacted on many areas of modern life. In the field of remediation perhaps most practical applications of nanotechnology have focussed on the use of zero valent iron as a treatment of organic contaminants in ground water (e.g. Li et al, 2006; Varanasi et al., 2007; Kim et al., 2017; Zhang et al., 2009; Crane and Scott, 2012; Fu et al., 2014). However, a challenge with the use of zero valent iron is the concern regarding the environmental fate of nanoparticles post injection into aquifers (Oughton et al., 2017). Another promising application of nanotechnology in the field of remediation focusses on the use of magnetic nanoparticles as there is the potential for recovery of the nanoparticles using magnets following deployment. Many studies have now investigated the use of magnetic nanoparticles, typically magnetite or maghemite, which are then functionalised with chelating agents to enable the particles to adsorb metal contaminants in a highly efficient way. The majority of these studies have currently been conducted in the laboratory using ideal solutions of single (Liu et al., 2009; Wang et al., 2011; Zhang et al., 2011; Figueira et al., 2011; Koehler et al., 2009; Afsar et al., 2014; Yen et al., 2017; Chung et al., 2012; Wang et al., 2015I Chen et al., 2014; Chen et al., 2016; Pan et al., 2016) or far less frequently, multiple (Zhang et al., 2011; Liu et al., 2008; Zeng et al., 2012; Hughes et al., 2017; Shan et al., 2015) potentially toxic metals. To increase levels of realism some studies have considered the impact of dissolved organic matter (DOM) on the efficiencies of metal removal by such nanoparticles, either through additions of organic acids to metal solutions (Zhang et al., 2012; Hughes et al., 2017) through the use of metal-amended natural waters (Figueira et al., 2011; Liu et al., 2008) or, rarely, the use of actual metal contaminated environmental solutions (Bao et al., 2016). 
In our previous study we described a synthetic method for preparing DTPA-functionalised maghemite nanoparticles and tested the efficiency of the nanoparticles for $\mathrm{Pb}$ and $\mathrm{Zn}$ removal from solution for both single and binary metal solutions and in the presence and absence of fulvic acid as a model form of DOM. Metal-bearing solutions arising from soil washing will contain a wider range of metals (both contaminant and non-contaminant) and a more diverse range of forms of DOM. Therefore, the aims of the current study were to consider the effectiveness of our nanoparticles for 1) adsorption of a wider range of metals ( $\mathrm{Ca}, \mathrm{Cd}, \mathrm{Co}, \mathrm{Cu}$ and $\mathrm{Mg}$ ) from solution and 2) extraction of metals from leachate obtained from metal contaminated soils. Our study is novel in the following respects. Firstly, it uses DTPA functionalised nanoparticles; despite the established chelating capacity of DTPA there are hardly any reports of the synthesis and use of DTPA-functionalised magnetic nanoparticles (Koehler et al., 2009; Zhao et al., 2015; Zhang et al., 2016; Hughes et al., 2017 to date that we are aware of). Secondly, and from the perspective of assessing the practical applications of this emerging technology more importantly, it uses soil leachate from metal contaminated soils resulting in mixed metal solutions with relatively high DOM contents and the presence of "non-toxic" metals such as Ca and Mg.

\section{Methods}

\section{DTPA-functionalised maghemite nanoparticles}

DTPA-functionalised maghemite nanoparticles were synthesised as previously described (Hughes et al., 2017). In brief, the maghemite nanoparticles were synthesised by the reaction of $\mathrm{Fe}^{2+}$ and $\mathrm{Fe}^{3+}$ ions present in $\mathrm{FeCl}_{2}$ and $\mathrm{FeCl}_{3}$ solutions in a 1:2 molar ratio in the presence of $2 \mathrm{M} \mathrm{NaOH}$ as a base. The nanoparticles were given a silica coating by reacting them in tetraethyl orthosilicate (TEOS) and an amine linker added to the surface via reaction with 3-aminopropyltriethoxysilane (APTES). The nanoparticles were washed in dimethylformamide (DMF) and the diethylenetriaminepentaacetic acid (DTPA) added to the amine linker by reaction with triethylamine (TEA) and DTPA dianhydride to give the final composite nanoparticle (Fig. 1). Finally the nanoparticles were washed four times in 


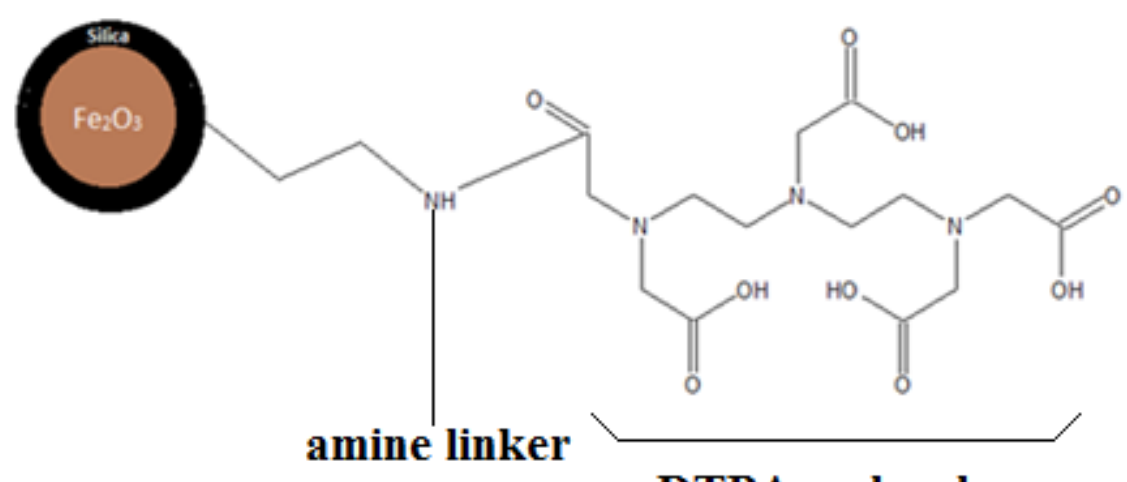

113

117 Extraction tests et al (2017).

\section{DTPA molecule}

Fig. 1. Theoretical structure of the silica coated DTPA-functionalised maghemite nanoparticle. temperature $\left(20^{\circ} \mathrm{C}\right)$. The nanoparticles were then removed from solution using a

methanol and stored in deionised water. The average diameter of the resulting particles was $47 \pm 6.9 \mathrm{~nm}$ (according to TEM). Full details of particle characterization are given in Hughes

The extraction tests (for both single metal solutions and soil leachates) followed the same basic protocol detailed in Hughes et al (2017). $2 \mathrm{~mL}$ of an aqueous suspension of DTPAfunctionalised nanoparticles (10 mg in total) were added to $8 \mathrm{~mL}$ of either a test solution containing a background electrolyte of $0.1 \mathrm{M} \mathrm{NaNO}_{3}$, to maintain a constant ionic strength in the extraction solutions (Yang et al. 2006) or a soil leachate. For fixed pH experiments the $\mathrm{pH}$ of the suspensions were adjusted by dropwise addition of $0.01 \mathrm{M} \mathrm{HCl}$ and $0.1 \mathrm{M} \mathrm{NaOH}$. pH was measured using a Jenway 3310 pH meter with a Fisherbrand FB68793 glass electrode. The $\mathrm{pH}$ meter was calibrated using $\mathrm{pH} 4$ and $\mathrm{pH} 7$ buffers. Calibration was conducted at the start of analysis and after every 10 samples. Following addition of the nanoparticles, each solution was shaken for 18 hours on an end-over-end shaker at constant neodymium permanent magnet and the solution analysed for the metal(s) of interest by either a Perkin Elmer 100B Atomic absorption spectrometer (AAS) or a Perkin Elmer 
131 OPTIMA 3000 inductively coupled plasma optimal emission spectrometer (ICP-OES). In the

132 single metal experiments, to check for nanoparticle stability and / or remnant nanoparticles in

133 suspension, Fe in solution was also analysed by AAS or ICP-OES. In all cases Fe was

134 below detection in solution indicating that the nanoparticles were stable and removal of at

135 least 99.99\% of the added nanoparticles (Hughes et al, 2017). Nanoparticle free controls were also run. All experiments were performed in triplicate. Metal extraction efficiency was calculated as the difference in concentration between the test and a control solution expressed as a percentage of the control solution concentration. Partition coefficients $\left(K_{d}\right)$ were calculated as the ratio of metal concentration on the nanoparticles to the metal concentration remaining in solution.

\section{Single metal solutions}

In the first set of experiments, solutions containing $10 \mathrm{mg} \mathrm{L}^{-1}$ of either $\mathrm{Ca}, \mathrm{Cd}, \mathrm{Co}, \mathrm{Cu}$ or $\mathrm{Mg}$ were used (though note that results are expressed in terms of moles to allow comparison between elements). The metals were introduced as nitrate salts and the $\mathrm{pH}$ was adjusted to $\mathrm{pH} 2,3,4,5,6,7$ and 8. Metal concentrations were analysed by AAS. Detection limits were $0.02 \mathrm{mg} \mathrm{L}^{-1}(\mathrm{Ca}), 0.01 \mathrm{mg} \mathrm{L}^{-1}(\mathrm{Cd}), 0.007 \mathrm{mg} \mathrm{L}^{-1}(\mathrm{Cu}), 0.009 \mathrm{mg} \mathrm{L}^{-1}(\mathrm{Co}), 0.001 \mathrm{mg} \mathrm{L}^{-1}(\mathrm{Fe})$, $0.001 \mathrm{mg} \mathrm{L}^{-1}(\mathrm{Mg}), 0.008 \mathrm{mg} \mathrm{L}^{-1}(\mathrm{~Pb})$ and $0.01 \mathrm{mg} \mathrm{L}^{-1}(\mathrm{Zn})$, whilst precision was $3.16 \%(\mathrm{Ca})$, 4.62\% (Cd), 2.99\% (Cu), 3.71\% (Co), 2.66\% (Fe), 3.40\% (Mg), 3.52\% (Pb) and 3.08\% ( $\mathrm{Zn})$. Accuracy was 98\% (Ca), 97\% (Cd), 98\% (Cu), 95\% (Co) and 96\% (Mg).

\section{Soil leachates}

For a second set of experiments, soils were collected from metal contaminated sites: Avonmouth (ST 532 803) a former Pb/Zn smelter, which was operational until 2003 (Nahmani et al. 2007); Barney Beck (SD 992 998), an episodically flooded pasture located near a small tributary of the River Swale in North Yorkshire, an area that was extensively mined for $\mathrm{Pb}$ from the Roman era up until the late $19^{\text {th }}$ Century when the mine was abandoned (Dennis, 2005); Cwmystwyth (SN 804 747) a former Pb/Zn mine site located in 
159 Ceredigion, central Wales that was mined from the beginning of the Roman era to 1950

160 (Hughes, 1981); Devon Great Consols (DGC) (SX 728 964) an abandoned Cu and As mine

161 which operated between 1844 and 1930 (Richardson, 1991); Graig Goch (SN 802 741) an abandoned $\mathrm{Pb}$ mine located in Ceredigion, central Wales and a part of the central Wales orefield (Palumbo-Roe, 2013); Redruth (SW 724 397) the former Tresavean Cu and Sn mine site, which ceased operating in 1928 (Dines, 1956); Rookhope (NY 894 441) a former Pb and fluorspar mine (Sizmur et al. 2011); Scunthorpe (SE 893 108) the site of the Buckingham allotments which have elevated soil As concentrations due to the underlying geology of the area which consists of arsenic rich Jurassic ironstone (Palumbo-Roe et al. 2005); Shipham (ST 448 573) a former Zn mining site, active in the $18^{\text {th }}$ and $19^{\text {th }}$ centuries in Somerset (Kiekens, 1995); and, Wisley (TQ 065 592) an uncontaminated sandy loam soil that was spiked with lead nitrate, copper sulphate and zinc sulphate in 2005 (Alexander et al. 2006). These soils were used to generate leachates that were in turn used to investigate the ability of the DTPA-functionalised nanoparticles to remove metals from mixed-metal solutions that also contained natural dissolved organic matter. This allowed an assessment of the potential use of the nanoparticles as a component of soil washing remedial treatments or to remediate metal-contaminated water courses. The soil leachates were prepared by adding $2.5 \mathrm{~g}$ of soil (air dried, $2 \mathrm{~mm}$ sieved) to $50 \mathrm{~mL}$ of ultrapure $\mathrm{H}_{2} \mathrm{O}$. This ratio was based on the 1:20 to 1:40 range of optimal ratios for extraction of metals from soil washing solutions using EDTA (Papassiopi et al., 1999). The suspension was shaken on an end over end shaker for 24 hours then centrifuged for 20 minutes at $3500 \mathrm{rpm}$. The supernatant was decanted off, producing the final soil leachate. The $\mathrm{pH}$ of the leachate was measured and then $10 \mathrm{mg}$ of nanoparticles in $2 \mathrm{~mL}$ of ultrapure water were added to $8 \mathrm{~mL}$ of leachate. After removal of the nanoparticles, solutions were syringe filtered using $0.45 \mu \mathrm{m}$ cellulose nitrate filters before being analysed for a range of metals by ICP-OES (As, Ca, Cd, Co, Cr, Cu, Fe, $\mathrm{Mg}, \mathrm{Na}, \mathrm{Ni}, \mathrm{P}, \mathrm{Pb}, \mathrm{Zn})$. Detection limits and precision were as follows: As $\left(1.3 \times 10^{-3} \mathrm{mg} \mathrm{L}^{-1}\right.$, $3.1 \%), \mathrm{Ca}\left(1.3 \times 10^{-3} \mathrm{mg} \mathrm{L}^{-1}, 2.6 \%\right), \mathrm{Cd}\left(8.9 \times 10^{-5} \mathrm{mg} \mathrm{L}^{-1}, 2.9 \%\right)$, Co $\left(1.6 \times 10^{-3} \mathrm{mg} \mathrm{L}^{-1}\right.$, 4.2\%), $\operatorname{Cr}\left(3.2 \times 10^{-4} \mathrm{mg} \mathrm{L}^{-1}, 3.9 \%\right), \mathrm{Cu}\left(1.3 \times 10^{-3} \mathrm{mg} \mathrm{L}^{-1}, 2.6 \%\right), \mathrm{Fe}\left(2.1 \times 10^{-3} \mathrm{mg} \mathrm{L}^{-1}, 4.5\right.$ 
\%), $\mathrm{Mg}\left(1.6 \times 10^{-4} \mathrm{mg} \mathrm{L}^{-1}, 2.5 \%\right), \mathrm{Na}\left(9.2 \times 10^{-4} \mathrm{mg} \mathrm{L}^{-1}, 3.1 \%\right), \mathrm{Ni}\left(3.3 \times 10^{-3} \mathrm{mg} \mathrm{L}^{-1}, 2.7 \%\right), \mathrm{P}$

Dissolved organic carbon (DOC) was measured using a Shimadzu TOC-L total carbon analyser equipped with a non-dispersive infra-red (NDIR) detector. The detection limit for the DOC was $1.31 \times 10^{-4} \mathrm{mg} \mathrm{L}^{-1}$ and the precision value for the 12 samples measured in duplicate was $\pm 2.4 \%$.

Statistical analysis

Data were analysed using SigmaPlot 12 for Windows.

\section{Results and Discussion}

\section{Single metal studies}

200 Metal concentrations in the control and nanoparticle-treated mono-metallic solutions are presented in Table 1 and calculated extraction efficiencies in Table 2. The decrease in control solution concentrations with increasing $\mathrm{pH}$ for $\mathrm{Cu}$ and, to a lesser extent $\mathrm{Cd}$ and $\mathrm{Co}$, indicate that some precipitation occurred at higher $\mathrm{pH}$ values for these metals. However, differences in concentration between the control and nanoparticle-treated solution concentrations at a given $\mathrm{pH}$ are indicative of adsorption as the metal removal process. $\mathrm{K}_{\mathrm{d}}$ values were calculated as the ratio of the concentration of metal on the nanoparticles at equilibrium concentrations $\left(\mathrm{mmol} \mathrm{kg}^{-1}\right)$ and the concentration of metal in solution at equilibrium ( $\mathrm{mmol} \mathrm{L}^{-1}$ ) for the extractions and are presented in Table 3. 
210 Table 1. Concentrations ( $\mathrm{mmol} \mathrm{L}^{-1}$ ) of metals in solution in control and nanoparticle treated solutions. Values are mean \pm standard deviations $(\mathrm{n}$

$211=3)$.

\begin{tabular}{|c|c|c|c|c|c|c|c|c|c|c|}
\hline & $\mathrm{Ca}$ & & $\mathrm{Cd}$ & & Co & & $\mathrm{Cu}$ & & $\mathrm{Mg}$ & \\
\hline $\mathrm{pH}$ & Control & NP & Control & NP & Control & NP & Control & NP & Control & NP \\
\hline 2 & $0.232 \pm 0.004$ & $0.223 \pm 0.001$ & $0.086 \pm 0.001$ & $0.032 \pm 0.003$ & $0.173 \pm 0.002$ & $0.033 \pm 0.013$ & $0.163 \pm 0.002$ & $0.022 \pm 0.00$ & $0.406 \pm 0.002$ & $0.402 \pm 0.006$ \\
\hline 3 & $0.233 \pm 0.003$ & $0.161 \pm 0.032$ & $0.085 \pm 0.001$ & $0.010 \pm 0.000$ & $0.171 \pm 0.002$ & $0.018 \pm 0.002$ & $0.158 \pm 0.001$ & $0.017 \pm 0.000$ & $0.416 \pm 0.004$ & $0.348 \pm 0.031$ \\
\hline 4 & $0.237 \pm 0.003$ & $0.090 \pm 0.008$ & $0.080 \pm 0.000$ & $0.006 \pm 0.002$ & $0.168 \pm 0.001$ & $0.017 \pm 0.001$ & $0.150 \pm 0.007$ & $0.026 \pm 0.002$ & $0.407 \pm 0.004$ & $0.337 \pm 0.026$ \\
\hline 5 & $0.227 \pm 0.001$ & $0.079 \pm 0.012$ & $0.065 \pm 0.001$ & $0.006 \pm 0.002$ & $0.169 \pm 0.001$ & $0.020 \pm 0.002$ & $0.154 \pm 0.003$ & $0.032 \pm 0.000$ & $0.410 \pm 0.002$ & $0.336 \pm 0.031$ \\
\hline 6 & $0.236 \pm 0.001$ & $0.080 \pm 0.004$ & $0.077 \pm 0.000$ & $0.007 \pm 0.002$ & $0.168 \pm 0.001$ & $0.019 \pm 0.001$ & $0.150 \pm 0.002$ & $0.026 \pm 0.000$ & $0.413 \pm 0.005$ & $0.339 \pm 0.016$ \\
\hline 7 & $0.228 \pm 0.002$ & $0.059 \pm 0.005$ & $0.077 \pm 0.003$ & $0.006 \pm 0.001$ & $0.152 \pm 0.001$ & $0.019 \pm 0.000$ & $0.067 \pm 0.004$ & $0.017 \pm 0.001$ & $0.410 \pm 0.002$ & $0.354 \pm 0.014$ \\
\hline 8 & $0.231 \pm 0.000$ & $0.057 \pm 0.007$ & $0.079 \pm 0.000$ & $0.006 \pm 0.000$ & $0.152 \pm 0.003$ & $0.020 \pm 0.000$ & $0.058 \pm 0.011$ & $0.012 \pm 0.002$ & $0.402 \pm 0.016$ & $0.391 \pm 0.008$ \\
\hline
\end{tabular}

212

213 
215 Table 2. Percentage extraction efficiencies of $\mathrm{Ca}, \mathrm{Cd}, \mathrm{Co}, \mathrm{Cu}, \mathrm{Mg}, \mathrm{Pb}$ and $\mathrm{Zn}$ from aqueous 216 solution by nanoparticles at $\mathrm{pH} 2$ to 8 . Values are mean \pm standard deviation, $\mathrm{n}=3 . \mathrm{Pb}$ and 217 Zn data from Hughes et al. (2017).

\begin{tabular}{llllllll}
\hline $\begin{array}{l}\mathrm{pH} \\
\text { Metal }\end{array}$ & 2 & 3 & 4 & 5 & 6 & 7 & 8 \\
\hline $\mathrm{Ca}$ & $3.6 \pm 0.54$ & $31 \pm 14$ & $62 \pm 3.3$ & $65 \pm 5.3$ & $66 \pm 1.9$ & $74 \pm 2.1$ & $75 \pm 3.0$ \\
$\mathrm{Cd}$ & $62 \pm 3.7$ & $89 \pm 0.57$ & $92 \pm 2.0$ & $91 \pm 2.8$ & $91 \pm 3.1$ & $92 \pm 1.4$ & $92 \pm 0.13$ \\
$\mathrm{Co}$ & $81 \pm 7.5$ & $90 \pm 1.2$ & $90 \pm 0.53$ & $88 \pm 1.2$ & $89 \pm 0.66$ & $87 \pm 0.23$ & $87 \pm 0.40$ \\
$\mathrm{Cu}$ & $86 \pm 0.17$ & $90 \pm 0.10$ & $82 \pm 1.5$ & $79 \pm 0.18$ & $82 \pm 0.060$ & $75 \pm 1.8$ & $79 \pm 3.2$ \\
$\mathrm{Mg}$ & $1.0 \pm 1.5$ & $16 \pm 7.4$ & $17 \pm 6.3$ & $18 \pm 7.6$ & $18 \pm 3.8$ & $14 \pm 3.5$ & $2.7 \pm 2.0$ \\
$\mathrm{~Pb}$ & $91 \pm 2.8$ & $97 \pm 0.32$ & $94 \pm 0.78$ & $95 \pm 0.92$ & $94 \pm 1.6$ & $62 \pm 9.4$ & $71 \pm 8.1$ \\
$\mathrm{Zn}$ & $76 \pm 10$ & $92 \pm 2.6$ & $92 \pm 1.8$ & $91 \pm 1.4$ & $91 \pm 1.7$ & $91 \pm 0.53$ & $88 \pm 0.26$ \\
\hline
\end{tabular}

219 Table 3. Metal partition coefficients $\left(\mathrm{K}_{\mathrm{d}} / \mathrm{L} \mathrm{kg}^{-1}\right)$ for $\mathrm{Cd}, \mathrm{Co}, \mathrm{Cu}, \mathrm{Pb}, \mathrm{Zn}, \mathrm{Ca}$ and $\mathrm{Mg}$ extraction 220 by nanoparticles between $\mathrm{pH} 2$ and 8 . Values are mean \pm standard deviation $(\mathrm{n}=3) . \mathrm{Pb}$ and

221 Zn values taken from Hughes et al (2017).

\begin{tabular}{cccccccc}
\hline $\mathrm{pH}$ & $\mathrm{Cd}$ & $\mathrm{Co}$ & $\mathrm{Cu}$ & $\mathrm{Pb}$ & $\mathrm{Zn}$ & $\mathrm{Ca}$ & $\mathrm{Mg}$ \\
\hline 2 & $1680 \pm 250$ & $5140 \pm 3190$ & $6270 \pm 88.1$ & $10800 \pm 4400$ & $4050 \pm 2850$ & $37.3 \pm 5.80$ & $10.4 \pm 15.9$ \\
3 & $7780 \pm 441$ & $8750 \pm 1070$ & $8580 \pm 91.2$ & $32800 \pm 3440$ & $12000 \pm 3560$ & $486 \pm 329$ & $200 \pm 112$ \\
4 & $12100 \pm 2950$ & $8630 \pm 483$ & $4700 \pm 494$ & $17300 \pm 2780$ & $12000 \pm 2660$ & $1650 \pm 222$ & $212 \pm 95.6$ \\
5 & $11000 \pm 3290$ & $7570 \pm 836$ & $3810 \pm 40.9$ & $18900 \pm 3760$ & $10000 \pm 1720$ & $1990 \pm 425$ & $228 \pm 120$ \\
6 & $11100 \pm 3570$ & $7870 \pm 520$ & $4670 \pm 19.4$ & $16000 \pm 4240$ & $10900 \pm 2440$ & $1960 \pm 171$ & $220 \pm 57.5$ \\
7 & $11400 \pm 1950$ & $6820 \pm 141$ & $3060 \pm 281$ & $1760 \pm 747$ & $10100 \pm 636$ & $2880 \pm 324$ & $160 \pm 47.8$ \\
8 & $12300 \pm 234$ & $6800 \pm 242$ & $3890 \pm 706$ & $2670 \pm 1140$ & $7560 \pm 189$ & $3120 \pm 499$ & $28.4 \pm 21.7$
\end{tabular}

222

223 Of the potentially toxic metals, extraction efficiency of $\mathrm{Cd}, \mathrm{Co}$ and $\mathrm{Cu}$ is in the same range as

224 that of $\mathrm{Pb}$ and $\mathrm{Zn}$ in our previous experiments (Hughes et al., 2017) and as reported for a

225 range of functionalised nanoparticles (e.g. Afsar et al., 2014; Liu et al., 2008; Liu et al., 2009;

226 Koehler et al., 2009; Zhang et al., 2011; the review of Lofrano et al., 2016; Table S1 in the

227 Supplementary Information). In depth comparison of extraction efficiencies found here and in

228 other studies is compromised by differences in initial solution composition and solid/liquid 
ratios. Two way Analysis of Variance (ANOVA) indicates that significant $(p \leq 0.01)$ differences are present between metals and between $\mathrm{pH}$ for both extraction efficiencies and $\mathrm{K}_{d}$ values and that there are significant interaction terms between the two. Extraction efficiency is greater for $\mathrm{Cd}, \mathrm{Co}, \mathrm{Cu}, \mathrm{Pb}$ and $\mathrm{Zn}$ than it is for $\mathrm{Ca}$ and $\mathrm{Mg}$ at all $\mathrm{pH}$ levels except at $\mathrm{pH} 7$ and 8 when extraction efficiency of Ca increases; relative to the other "toxic" metals $\mathrm{Cd}$ shows reduced extraction efficiency at $\mathrm{pH} 2$ and $\mathrm{Cu}$ at $\mathrm{pHs} 4-6$. Pb extraction efficiency decreases at $\mathrm{pH} 7$ and 8 . In general $\mathrm{K}_{d} \mathrm{~S}$ of $\geq 500 \mathrm{~L} \mathrm{~kg}^{-1}$ are considered acceptable and $>5000 \mathrm{mg} / \mathrm{L}$ very good (Fryxell et al., 2005). Thus the $\mathrm{K}_{d} \mathrm{~S}$ determined for our nanoparticles across a range of potentially toxic metals are suggestive of them being a useful adsorbent. $\mathrm{Ca}$ and $\mathrm{Mg}$ always have the lowest $\mathrm{K}_{\mathrm{d}} \mathrm{S}$. Similar results are reported in other studies using functionalised nanoparticles.

The iso-electric point of the nanoparticles is 6.74 (Hughes et al., 2017). Thus whilst our previous data suggest that adsorption of the metals is most likely dominated by chelation with the nitrogen atoms in the DTPA (Hughes et al., 2017) for $\mathrm{pH} \leq 6$ ion exchange with protons on the protonated functional groups of the DTPA and for $\mathrm{pH} \geq 7$ electrostatic adsorption to deprotonated functional groups of the DTPA is also likely to occur. The differences in efficiencies and $K_{d} s$ between the different metals are due in part to the metalDTPA complexation stability constants for the potentially toxic metals tested being higher than those for Ca and Mg (e.g. Lindsay et al., 1979; Dojino, 2017; Liu et al., 2008). However, in addition, as initial concentrations in solutions for the single metal tests were equal for all metals on a mg L $\mathrm{L}^{-1}$ basis the different atomic masses of the elements result in differing molar concentrations which may also have an impact. For example, both $\mathrm{Ca}$ and $\mathrm{Mg}$ have lower atomic masses than the toxic metals and therefore their molar concentrations are higher. Adsorption sites on the nanoparticles are potentially closer to saturation in the $\mathrm{Ca}$ and $\mathrm{Mg}$ extraction tests which may reduce extraction efficiency. 
The reduced extraction efficiency of $\mathrm{Cd}$ at $\mathrm{pH} 2$ compared to $\mathrm{Cu}$ and $\mathrm{Pb}$ (Hughes et al., 2017) is consistent with previous studies using EDTA-functionalised nanoparticles (Koehler et al., 2009; Zhang et al., 2011) and is due to the lowering of the $\mathrm{pH}$-dependent complex formation constant (Anderegg et al., 1959). Reduced extraction efficiency of Cu relative to $\mathrm{Cd}$ and $\mathrm{Pb}$ at similar concentrations to those used in our experiment has been previously observed at pH 6 (Koehler et al., 2009) and pH 5 (Zhang et al. 2011) and attributed to the lower molar concentration of $\mathrm{Cd}$ and $\mathrm{Pb}$ solutions relative to $\mathrm{Cu}$ for solutions of the same concentration by mass leading to increased saturation levels of adsorption sites for the $\mathrm{Cu}$. The high extraction efficiency and $\mathrm{K}_{d}$ values for $\mathrm{Pb}$ at $\mathrm{pH} 2-6$ are consistent with a number of other studies using a variety of functionalised nanoparticles (Koehler et al., 2009; Zhang et al., 2011; Liu et al, 2009; Liu et al., 2008) and are related to high stability constants and the low molar concentration of $\mathrm{Pb}$ in the test solution relative to the other metals. We have discussed the reduced extraction efficiency and $\mathrm{K}_{d}$ values of $\mathrm{Pb}$ at $\mathrm{pH} 7$ and 8 previously (Hughes et al., 2017); it is consistent with previous studies on a variety of functionalised nanoparticles and is attributed to changes in speciation at these $\mathrm{pH}$ values (Hughes et al., 2017; Wang et al., 2015; Weng, 2004; Liu et al., 2009).

Similar to other studies on a variety of chelating agent functionalised magnetic nanoparticles (e.g. Chen et al., 2016; Liu et al., 2008; Liu et al., 2009; Shi et al., 2016; Zhang et al., 2012, Zhang et al., 2011; Table S1 in Supporting Information) our single metal extraction experiments show that our functionalised nanoparticles can extract a range of contaminant metals. This is to be expected as the chelating agents used to functionalise the nanoparticles are not specific for a single metal. This is encouraging for use of functionalised nanoparticles in real world situations where mixed metal contamination is more likely than single metal contamination. However, although previous studies have shown the capacity of functionalised nanoparticles to maintain high extraction efficiencies in mixed metal solutions often containing high concentrations of nontoxic elements such as $\mathrm{Ca}$ and $\mathrm{Mg}$ (e.g. Hughes 
et al., 2017; Liu et al., 2008; Shan et al., 2015; Zhang et al., 2012) extraction efficiency can be reduced relative to single metal solutions (e.g. Hughes et al., 2017; Liu et al., 2008; Zhang et al., 2011). Ca and Mg often occur at high concentrations in soils ( $\mathrm{Ca}=1-200 \mathrm{~g} \mathrm{~kg}^{-1}$; $\mathrm{Mg}=0.1-28.6 \mathrm{~g} \mathrm{~kg}^{-1}$ ) (Bolan et al. 2004) and solutions and leachates from soil could therefore contain higher concentrations of such elements than concentrations considered in experiments to date. Similarly although previous studies have shown high levels of metal extraction in the presence of DOC (Hughes et al., 2017; Liu et al., 2008; Shan et al., 2015; Zhang et al. 2012) our previous experiments (Hughes et al., 2017) also showed significant reductions in extraction efficiency at concentrations of $2.1 \mathrm{mg} \mathrm{L}^{-1}$ and $21 \mathrm{mg} \mathrm{L}^{-1} \mathrm{DOC}$. Metalrich extracts obtained by leaching soils with water may contain higher concentrations of DOC than this which could potentially have an impact on the extraction efficiency of toxic metals from such soils. Therefore to investigate further the potential use of our DTPA-functionalised nanoparticles for removal of metal from the aqueous leachates of contaminated soils, we determined extraction efficiencies using leachates from soils containing a mixture of inorganic contaminants and variable, native concentrations of DOC.

\section{Soil extractions}

The chemistry of the soil leachates in control and nanoparticle-present treatments is presented in Tables 4 and 5. All the leachates were filtered to $0.45 \mu \mathrm{m}$ prior to use. Operationally we have assumed that this filtration step results in the production of a pure solution and that differences between control and nanoparticle-present treatments are therefore due to interactions between ions in solution and the added nanoparticles. We did not analyse our filtered solutions for the presence of colloids but these may be present and have an impact on our results. However, from a practical perspective the aim of our investigation was to determine whether our nanoparticles were effective at removing metals from leachates obtained from metal contaminated soils regardless of whether colloidal particles play a role or not. The leachates contain relatively low concentrations of metals 
despite samples being taken from former mine sites with soils that have high total metal concentrations reported in the literature; this reflects the speciation of the metals in the soils and highlights the important difference between concentrations of "total" metals compared to other fractions such as "bioavailable", "bioaccessible" and "mobile". The Scunthorpe soil is a good example of this. Palumbo-Roe et al (2005) report elevated As concentrations in soils taken from this sample locality but also that the majority of this As is not bio-accessible. Further the $\mathrm{pH}$ of the leachate (c. neutral) lies in the range where As sorption to Fe oxides is high which reduces the likelihood of As passing into solution (Dixit and Hering, 2003; Partey et al. 2008). However, in this study we are not concerned with the issue of bioavailability of metals in soils. Rather, the contaminated soils were used to generate leachates containing metals which could be used to determine the ability of the DTPA-functionalised nanoparticles to remove metals from mixed metal solutions that also contained dissolved organic matter. This allowed us to assess the potential use of the nanoparticles as a stage in soil washing remedial treatments and / or for remediating metal-contaminated natural waters.

The total concentration of "non toxic" elements $(\mathrm{Ca}, \mathrm{Mg}, \mathrm{Na})$ in the control leachate was significantly greater ( $p \leq 0.05$, Kruskal-Wallis analysis of variance on ranks) than that of the total concentration of potentially toxic elements (As, Cd, Co, Cr, Cu, Pb, Zn). Despite this the nanoparticles removed significantly more toxic than non-toxic (either $\mathrm{Ca}+\mathrm{Mg}$ or $\mathrm{Ca}+\mathrm{Mg}+\mathrm{Na}$ ) elements from solution ( $p \leq 0.05$, Kruskal-Wallis analysis of variance on ranks). Out of the 10 soils studied, where there are significant differences ( $p \leq 0.05$; t-tests) between the concentrations in the nanoparticle-present and control treatments (As -4 soils, $\mathrm{Cd}-4$ soils, $\mathrm{Cu}-4$ soils, $\mathrm{Pb}-5$ soils, $\mathrm{Zn}-6$ soils), the nanoparticle-present treatments contain lower concentrations of potentially toxic metals than the controls. $\mathrm{Cd}, \mathrm{Cu}, \mathrm{Pb}$ and $\mathrm{Zn}$ would be present as cations under the solution conditions whereas As would be present as an oxyanion. As with the single element extractions, adsorption of the cations is most likely dominated by chelation but will also involve, depending on $\mathrm{pH}$, ion exchange or electrostatic 
336 adsorption whilst adsorption of the As is most likely due to non-specific adsorption between

337 the As oxyanion and the protonated nanoparticle surface.

338

339 With respect to the effect of the nanoparticle treatment on concentrations of the major, non-

340 toxic elements, Na usually has significantly higher concentrations in the nanoparticle-present

341 treatments (7 out of 8 soils) whereas $\mathrm{Mg}$ was lower in the nanoparticle-present leachates for

342 two soils (Avonmouth and Cwmystwyth) and Ca showed no consistent trend in the two soils

343 (Avonmouth and Barney Beck) where there were significant differences. The production of

344 the nanoparticles involves precipitation of Fe oxide in $2 \mathrm{M} \mathrm{NaOH}$. Despite subsequent

345 washing stages, the most obvious explanation for the increase in $\mathrm{Na}$ in solution on addition

346 of the nanoparticles to the leachates is that residual $\mathrm{Na}^{+}$is still present associated with the

347 nanoparticles. 
Table 4. Mean concentrations ( $\mu \mathrm{mol} \mathrm{L}^{-1}$ ) of metals in control (cont) and nanoparticle (NP)-treated soil leachate. Values are mean \pm standard deviations $(n=3)$. BDL indicates concentration below detection limit. Bold italics indicate a significant difference $(\boldsymbol{p} \leq \mathbf{0 . 0 5} \boldsymbol{t} \boldsymbol{t}$-test) between control and nanoparticle present solution element concentrations. For statistical analysis of solutions where concentrations were below detection limits, concentrations were fixed at the detection limit. Avon = Avonmouth, Barn = Barney Beck, Cwm = Cwmystwyth, DGC $=$ Devon Great Consols, Graig= Graig Goch, Red - Red Ruth, Rook = Rookhope, Scun = Scunthorpe, Ship $=$ Shipham, Wis $=$ Wisley.

\begin{tabular}{|c|c|c|c|c|c|c|c|c|c|c|c|}
\hline Soil & Treatment & As & $\mathrm{Ca}$ & $\mathrm{Cd}$ & Co & $\mathrm{Cr}$ & $\mathrm{Cu}$ & $\mathrm{Mg}$ & $\mathrm{Na}$ & $\mathrm{Pb}$ & $\mathrm{Zn}$ \\
\hline \multirow{2}{*}{ Avon } & cont & $0.241 \pm 0.075$ & $415 \pm 10.8$ & $8.46 \pm 0.380$ & $\begin{array}{l}0.167 \pm \\
0.00348\end{array}$ & $\begin{array}{l}0.151 \pm \\
0.116\end{array}$ & $9.01 \pm 0.997$ & $145 \pm 22.2$ & $82.4 \pm 11.1$ & $7.89 \pm 2.11$ & $579 \pm 22.8$ \\
\hline & NP & $B D L$ & $376 \pm 15.7$ & $6.48 \pm 0.271$ & $\begin{array}{l}0.142 \pm \\
0.0145\end{array}$ & $\begin{array}{l}0.00900 \pm \\
0.00417\end{array}$ & $1.19 \pm 0.213$ & $1.70 \pm 2.30$ & $119 \pm 3.05$ & $B D L$ & $473 \pm 19.9$ \\
\hline \multirow{2}{*}{ Barn } & cont & $\mathrm{BDL}$ & $118 \pm 2.25$ & $\begin{array}{l}0.00226 \pm \\
0.000111\end{array}$ & $\mathrm{BDL}$ & $\begin{array}{l}0.0615 \pm \\
0.0271\end{array}$ & $\begin{array}{l}0.0197 \pm \\
0.00143\end{array}$ & $16.4 \pm 2.06$ & $47.1 \pm 0.415$ & $\begin{array}{l}0.686 \pm \\
0.183\end{array}$ & $\begin{array}{l}0.701 \pm \\
0.204\end{array}$ \\
\hline & NP & $\mathrm{BDL}$ & $130 \pm 5.39$ & $B D L$ & BDL & $\begin{array}{l}0.0621 \pm \\
0.0137\end{array}$ & $\begin{array}{l}0.0241 \pm \\
0.00388\end{array}$ & $17.3 \pm 1.91$ & $104 \pm 8.08$ & $\begin{array}{l}0.143 \pm \\
0.0826\end{array}$ & $\begin{array}{l}0.270 \pm \\
0.213\end{array}$ \\
\hline \multirow{2}{*}{ Cwm } & cont & $\mathrm{BDL}$ & $\begin{array}{l}14.7 \pm \\
4.65\end{array}$ & $\begin{array}{l}0.0150 \pm \\
0.0000489\end{array}$ & $\begin{array}{l}0.0293 \pm \\
0.00361\end{array}$ & $\begin{array}{l}0.0210 \pm \\
0.0193\end{array}$ & $\begin{array}{l}0.132 \pm \\
0.0470\end{array}$ & $10.2 \pm 0.554$ & $31.4 \pm 2.54$ & $1.53 \pm 0.618$ & $\begin{array}{l}11.3 \pm \\
0.704\end{array}$ \\
\hline & NP & $\mathrm{BDL}$ & $10.2 \pm 2.39$ & $\mathrm{BDL}$ & $\mathrm{BDL}$ & $\begin{array}{l}0.00822 \pm \\
0.00359\end{array}$ & $\begin{array}{l}0.0663 \pm \\
0.00695\end{array}$ & $7.42 \pm 1.00$ & $78.5 \pm 2.62$ & $\begin{array}{l}0.075 \pm \\
0.000503\end{array}$ & $\begin{array}{l}2.07 \pm \\
1.45\end{array}$ \\
\hline \multirow{2}{*}{ DGC } & cont & $2.27 \pm 0.101$ & $107 \pm 11.9$ & $\mathrm{BDL}$ & $\begin{array}{l}0.0755 \pm \\
0.00810\end{array}$ & $\mathrm{BDL}$ & $11.7 \pm 1.73$ & $16.2 \pm 2.17$ & $15.9 \pm 1.20$ & $\mathrm{BDL}$ & $\begin{array}{l}1.44 \pm \\
0.508\end{array}$ \\
\hline & NP & $1.129 \pm 0.0449$ & $111 \pm 1.42$ & BDL & $\begin{array}{l}0.0633 \pm \\
0.00713\end{array}$ & BDL & $\begin{array}{l}0.247 \pm \\
0.146\end{array}$ & $16.5 \pm 0.304$ & $66.1 \pm 2.54$ & BDL & $\begin{array}{l}0.626 \pm \\
0.285\end{array}$ \\
\hline \multirow{2}{*}{ Graig } & cont & $\mathrm{BDL}$ & $\begin{array}{l}16.2 \pm \\
0.683\end{array}$ & $\begin{array}{l}0.157 \pm \\
0.00535\end{array}$ & $\begin{array}{l}0.109 \pm \\
0.0183\end{array}$ & $\begin{array}{l}0.00676 \pm \\
0.00105\end{array}$ & $\begin{array}{l}0.383 \pm \\
0.00204\end{array}$ & $12.4 \pm 0.656$ & $28.3 \pm 12.0$ & $41.4 \pm 0.591$ & $\begin{array}{l}75.9 \pm \\
1.83\end{array}$ \\
\hline & NP & $\mathrm{BDL}$ & $\begin{array}{l}18.0 \pm \\
0.909\end{array}$ & $\begin{array}{l}0.0946 \pm \\
0.0107\end{array}$ & $\begin{array}{l}0.0904 \pm \\
0.00569\end{array}$ & $\begin{array}{l}0.00635 \pm \\
0.000342\end{array}$ & $\begin{array}{l}0.0787 \pm \\
0.0236\end{array}$ & $11.4 \pm 0.293$ & $71.3 \pm 3.15$ & $\begin{array}{l}0.228 \pm \\
0.145\end{array}$ & $\begin{array}{l}51.0 \pm \\
7.39\end{array}$ \\
\hline \multirow{2}{*}{ Red } & cont & $\mathrm{BDL}$ & $636 \pm 47.5$ & $\mathrm{BDL}$ & $\mathrm{BDL}$ & $\mathrm{BDL}$ & $\begin{array}{l}0.0384 \pm \\
0.00696\end{array}$ & $14.9 \pm 0.842$ & $90.4 \pm 3.25$ & $\mathrm{BDL}$ & $\begin{array}{l}0.459 \pm \\
0.212\end{array}$ \\
\hline & NP & BDL & $681 \pm 47.4$ & BDL & BDL & $0.0330 \pm$ & $\begin{array}{l}0.0325 \pm \\
0.0112\end{array}$ & $18.8 \pm 2.75$ & $35.4 \pm 1.96$ & BDL & $\begin{array}{l}0.0404 \pm \\
0.00485\end{array}$ \\
\hline \multirow{2}{*}{ Rook } & cont & $\begin{array}{l}0.0764 \pm \\
0.0124\end{array}$ & $308 \pm 26.4$ & $\begin{array}{l}0.0181 \pm \\
0.000750\end{array}$ & $\begin{array}{l}0.166 \pm \\
0.0701\end{array}$ & $\begin{array}{l}0.0600 \pm \\
0.0476\end{array}$ & $\begin{array}{l}0.0429 \pm \\
0.0293\end{array}$ & $53.4 \pm 2.72$ & $38.5 \pm 2.54$ & $3.38 \pm 1.46$ & $\begin{array}{l}8.59 \pm \\
0.966\end{array}$ \\
\hline & NP & $\begin{array}{l}0.0400 \pm \\
0.00467\end{array}$ & $301 \pm 3.37$ & $B D L$ & $\begin{array}{l}0.126 \pm \\
0.0141\end{array}$ & $\begin{array}{l}0.0200 \pm \\
0.00547\end{array}$ & $\begin{array}{l}0.024 \pm \\
0.0118\end{array}$ & $49.6 \pm 0.820$ & $85.7 \pm 5.68$ & $\begin{array}{l}0.952 \pm \\
0.0782\end{array}$ & $\begin{array}{l}1.50 \pm \\
0.532\end{array}$ \\
\hline \multirow{2}{*}{ Scun } & cont & $0.181 \pm 0.157$ & $549 \pm 403$ & $\begin{array}{l}0.00671 \pm \\
0.00519\end{array}$ & $\begin{array}{l}0.119 \pm \\
0.0259\end{array}$ & $\begin{array}{l}0.214 \pm \\
0.250\end{array}$ & $\begin{array}{l}0.135 \pm \\
0.187\end{array}$ & $72.1 \pm 34.3$ & $140 \pm 72.2$ & BDL & $\begin{array}{l}0.718 \pm \\
0.525\end{array}$ \\
\hline & NP & $0.230 \pm 0.0552$ & $335 \pm 35.8$ & $\begin{array}{l}0.00792 \pm \\
0.00413\end{array}$ & $\begin{array}{l}0.150 \pm \\
0.0470\end{array}$ & $\begin{array}{l}0.278 \pm \\
0.0890\end{array}$ & $\begin{array}{l}0.0255 \pm \\
0.00346\end{array}$ & $73.5 \pm 11.9$ & $129 \pm 12.2$ & $\mathrm{BDL}$ & $\begin{array}{l}0.600 \pm \\
0.101\end{array}$ \\
\hline \multirow{2}{*}{ Ship } & cont & $0.546 \pm 0.0948$ & $337 \pm 3.71$ & $\begin{array}{l}0.787 \pm \\
0.0366\end{array}$ & $\begin{array}{l}0.119 \pm \\
0.0555\end{array}$ & $\begin{array}{l}0.0407 \pm \\
0.0212\end{array}$ & $\begin{array}{l}0.0314 \pm \\
0.00786\end{array}$ & $144 \pm 4.93$ & $61.9 \pm 9.30$ & $\begin{array}{l}0.839 \pm \\
0.284\end{array}$ & $177 \pm 3.71$ \\
\hline & NP & $0.400 \pm 0.0501$ & $343 \pm 9.01$ & $\begin{array}{l}0.521 \pm \\
0.0247\end{array}$ & $\begin{array}{l}0.210 \pm \\
0.0595\end{array}$ & $\begin{array}{l}0.0126 \pm \\
0.00593\end{array}$ & $\begin{array}{l}0.0357 \pm \\
0.00168\end{array}$ & $146 \pm 3.83$ & $111 \pm 3.34$ & $\begin{array}{l}0.263 \pm \\
0.288\end{array}$ & $148 \pm 5.95$ \\
\hline \multirow{2}{*}{ Wis } & cont & $\begin{array}{l}0.0666 \pm \\
0.00387\end{array}$ & $417 \pm 14.3$ & $\begin{array}{l}0.00435 \pm \\
0.00125\end{array}$ & $\begin{array}{l}0.166 \pm \\
0.0266\end{array}$ & $\begin{array}{l}0.0181 \pm \\
0.00358\end{array}$ & $\begin{array}{l}1.05 \pm \\
0.0368\end{array}$ & $51.9 \pm 1.31$ & $35.6 \pm 2.18$ & $\begin{array}{l}0.145 \pm \\
0.0187\end{array}$ & $\begin{array}{l}2.04 \pm \\
0.0316\end{array}$ \\
\hline & NP & $\begin{array}{l}0.0409 \pm \\
0.00306\end{array}$ & $424 \pm 2.57$ & $\begin{array}{l}0.00292 \pm \\
0.00195\end{array}$ & $\begin{array}{l}0.137 \pm \\
0.0279\end{array}$ & $\begin{array}{l}0.00839 \pm \\
0.00388\end{array}$ & $\begin{array}{l}0.828 \pm \\
0.0336\end{array}$ & $50.6 \pm 1.21$ & $101 \pm 3.33$ & $B D L$ & $\begin{array}{l}1.24 \pm \\
0.517\end{array}$ \\
\hline \multicolumn{2}{|c|}{ Detection Limit } & 0.0174 & 0.0324 & 0.0008 & 0.0272 & 0.0062 & 0.0205 & 0.0066 & 0.04 & 0.0579 & 0.013 \\
\hline
\end{tabular}


354 Table 5. Leachate $\mathrm{pH}$ and dissolved organic carbon content / $\mathrm{mg} \mathrm{L}^{-1}$ in control (cont) and 355 nanoparticle (NP)-treated soil leachate. Soil names are as specified in the legend for Table 356 4. Values are means \pm standard deviation $(n=3)$.

\begin{tabular}{|c|c|c|c|}
\hline Soil & Treatment & $\mathrm{pH}$ & $\begin{array}{l}\text { Dissolved } \\
\text { organic carbon }\end{array}$ \\
\hline \multirow{2}{*}{ Avon } & cont & $5.32 \pm 0.20$ & $9.16 \pm 1.73$ \\
\hline & NP & $5.17 \pm 0.07$ & $10.0 \pm 0.375$ \\
\hline \multirow{2}{*}{ Barn } & cont & $6.94 \pm 0.40$ & $22.1 \pm 23.1^{1}$ \\
\hline & NP & $6.78 \pm 0.09$ & $23.6 \pm 24.5^{2}$ \\
\hline \multirow{2}{*}{ Cwm } & cont & $5.44 \pm 0.05$ & $15.5 \pm 0.633$ \\
\hline & NP & $5.43 \pm 0.13$ & $18.7 \pm 0.522$ \\
\hline \multirow{2}{*}{ DGC } & cont & $4.48 \pm 0.12$ & $1.85 \pm 0.233$ \\
\hline & NP & $4.38 \pm 0.05$ & $2.66 \pm 0.206$ \\
\hline \multirow{2}{*}{ Graig } & cont & $4.41 \pm 0.32$ & $9.69 \pm 0.600$ \\
\hline & NP & $4.44 \pm 0.18$ & $10.8 \pm 0.510$ \\
\hline \multirow{2}{*}{ Red } & cont & $7.70 \pm 0.21$ & $11.2 \pm 0.576$ \\
\hline & NP & $7.51 \pm 0.29$ & $15.6 \pm 2.25$ \\
\hline \multirow{2}{*}{ Rook } & cont & $6.30 \pm 0.11$ & $10.7 \pm 0.924$ \\
\hline & NP & $5.90 \pm 0.06$ & $11.5 \pm 0.454$ \\
\hline \multirow{2}{*}{ Scun } & cont & $7.74 \pm 0.38$ & $7.11 \pm 3.63$ \\
\hline & NP & $7.71 \pm 0.31$ & $7.56 \pm 2.09$ \\
\hline \multirow{2}{*}{ Ship } & cont & $5.79 \pm 0.06$ & $30.9 \pm 2.42$ \\
\hline & NP & $5.53 \pm 0.12$ & $30.9 \pm 5.13$ \\
\hline \multirow{2}{*}{ Wis } & cont & $6.98 \pm 0.33$ & $19.2 \pm 6.14$ \\
\hline & NP & $6.52 \pm 0.23$ & $20.9 \pm 6.17$ \\
\hline
\end{tabular}

$357{ }^{1}$ individual values were 48.8, 9.7 and $7.9 \mathrm{mg} \mathrm{L}^{-1}$. The initial value is likely to be an error which would give a mean composition 358 of $8.8 \pm 1.3 \mathrm{mg} \mathrm{L}^{-1}$

3592 individual values were $51.9,10.4$ and $8.6 \mathrm{mg} \mathrm{L}^{-1}$. The initial value is likely to be an error which would give a mean composition of $9.5 \pm 1.3 \mathrm{mg} \mathrm{L}^{-1}$ 
362 The lower concentrations of $\mathrm{Mg}$ in the nanoparticle-present treatments seems most likely to

363 be due to adsorption of $\mathrm{Mg}$, despite the relatively low Mg-DTPA complexation stability constants (e.g. Lindsay et al., 979; Dojino, 2017; Liu et al., 2008) and adsorption efficiencies measured in our single metal experiments.

366

367 Extraction efficiencies (Table 6) were calculated for the metals that showed significant reductions in concentration between the controls and the nanoparticle treatments.

Table 6. Percentage extraction efficiencies from soil solutions by nanoparticles where nanoparticles cause a significant decrease in solution concentration. Values are mean \pm standard deviations $(n=3)$. Soil names are as specified in the legend for Table 4 .

\begin{tabular}{llllll}
\hline $\begin{array}{l}\text { Metal } \\
\text { Soil }\end{array}$ & As & $\mathrm{Cd}$ & $\mathrm{Cu}$ & $\mathrm{Pb}$ & $\mathrm{Zn}$ \\
\hline Avon & $93 \pm 0$ & $23 \pm 3.2$ & $87 \pm 2.4$ & $97 \pm 4.8$ & $18 \pm 3.4$ \\
Barn & - & $62 \pm 4.8$ & - & $79 \pm 12$ & - \\
Cwm & - & - & - & $95 \pm 0.033$ & $82 \pm 13$ \\
DGC & $37 \pm 16$ & - & $97 \pm 0.70$ & - & - \\
Graig & - & $40 \pm 6.8$ & $79 \pm 6.1$ & $99 \pm 0.35$ & $33 \pm 9.7$ \\
Red & - & - & - & - & $91 \pm 1.1$ \\
Rook & $48 \pm 6.1$ & $91 \pm 8.1$ & - & - & $83 \pm 6.2$ \\
Scun & - & - & - & - & - \\
Ship & - & - & - & - & $16 \pm 3.4$ \\
Wis & $39 \pm 4.6$ & - & $21 \pm 3.2$ & $60 \pm 0$ & $39 \pm 25$ \\
\hline
\end{tabular}

Extraction efficiencies are variable between soils (no significant differences for As, ANOVA on Ranks; significant differences for $\mathrm{Cd}$ and $\mathrm{Cu}$ between all soils, ANOVA and Holm-Sidak multiple comparisons; between Graig Goch and Wisley for $\mathrm{Pb}$ and between Redruth and Shipham for Zn, ANOVA on ranks and Tukey test multiple comparisons) and are similar or lower to those obtained from the single metal solutions (Table 2). These results are consistent with previous findings in which extraction efficiencies of metals from mixtures are high and either unaffected or reduced by the presence of multiple metals, presumably due to competition for adsorption sites and preferential adsorption (Zhang et al., 2012; Liu et al., 2008; Zhang et al., 2011, Hughes et al., 2017; Shan et al., 2015) with precise trends 
depending on a range of variables including the metal concentration, $\mathrm{pH}$ and nanoparticle concentration. Additionally there will be competition for metal binding between the adsorption sites on the nanoparticles and complexation sites on the dissolved organic matter present in solution. In our study Zn extraction efficiencies in particular appear to be depressed compared to the typical range $(70-90 \%)$ found in single metal extraction experiments which is consistent with our previous findings from mixed $\mathrm{Pb}-\mathrm{Zn}$ solutions (Hughes et al., 2017). $\mathrm{Pb}$ extraction efficiencies remain high except for from the Wisley soil which has a relatively high $\mathrm{pH}$. Reduced $\mathrm{Pb}$ extraction at high $\mathrm{pH}$ is consistent with our previous findings on the effect of $\mathrm{pH}$ on $\mathrm{Pb}$ extraction (Hughes et al., 2017). Considering individual replicates rather than mean values the DOC content of the control leachate was in the range $2-49 \mathrm{mg} \mathrm{L}^{-1}$ with no significant differences (two-way ANOVA, $p \geq 0.05$ ) between the DOC content of the control and treated leachates. The maximum DOC values are higher than those in previous studies (e.g. Zhang et al., 2012; Liu et al., 2008; Shan et al., 2015; Hughes et al., 2017) where extraction efficiencies have been found to remain high but have been reduced by the presence of the DOC. Thus our results indicate that even in the presence of dissolved organic matter, the nanoparticles could be used to remove metals from solution. There were insufficient data to perform meaningful multiple regression analysis to determine any controlling variables for extraction efficiency. Correlation analysis between the extraction efficiency of individual metals and the $\mathrm{pH}, \mathrm{DOC}$, individual metal concentration and total metal concentration in controls for $\mathrm{As}, \mathrm{Cd}, \mathrm{Cu}, \mathrm{Pb}$ and $\mathrm{Zn}$ only gave a significant correlation for $\% \mathrm{~Pb}$ extraction and $\mathrm{pH}(\mathrm{r}=-0.89, \mathrm{p} \leq 0.05)$.

$\mathrm{K}_{\mathrm{d}}$ values were calculated for metals that showed a significant decrease in concentration between the controls and nanoparticle treatments (Table 7). The $K_{d}$ for specific metals largely show no significant differences between soils. The $K_{d}$ values for individual elements determined from the soil samples were usually either significantly lower (16 out of 40 values) or had no significant difference (21 out of 40 values) compared to the $\mathrm{K}_{d}$ values obtained on single metal solutions at similar $\mathrm{pH}$ values. The lower $\mathrm{K}_{d}$ values relative to those obtained 
412 from single metal solutions are consistent with the reduced extraction efficiencies observed

413 and again, reflect competition for adsorption sites and competition between adsorption on

414 the nanoparticles and complexation with the dissolved organic matter. Despite the reductions in $\mathrm{K}_{d}$ values, they are still typically $>500 \mathrm{~L} \mathrm{~kg}^{-1}$ and many are $>5000 \mathrm{~L} \mathrm{~kg}^{-1}$ indicating the potential for the nanoparticles to be used as adsorbents (Fryxell et al., 2005).

417 As with the extraction efficiency data, there were insufficient data to carry out multiple linear regression to determine controlling variables on the $\mathrm{K}_{d}$ values. There were no correlations between the $\mathrm{K}_{d}$ for a particular metal and the $\mathrm{pH}, \mathrm{DOC}$, individual metal concentration and total metal concentration in the controls. The reduction in $\mathrm{K}_{d}$ values compared to singlemetal solutions and the lack of extraction of some elements from the leachates despite the presence of those elements in solution indicates the importance for more studies such as this one in which real, rather than synthetic, metal-bearing solutions are used to test the potential of novel sorbents for remediation.

Due to the significant variation between the different soil leachates used in our study in terms of $\mathrm{pH}$, metal concentration, $\mathrm{DOC}$ and also the variations between this study and others in the literature (again $\mathrm{pH}$, metal concentration, $\mathrm{DOC}$ but also the nature of the chelating agent added to the magnetic nanoparticles), together with the paucity of multielement studies using real solutions in the literature it is difficult to make comparisons that are other than rather general as above. However, this study further demonstrates the potential for chelating agent functionalised magnetic nanoparticles to remove a range of metal contaminants from contaminated solutions and indicates that dissolved organic carbon and relatively high concentrations of non-toxic elements should not necessarily reduce the efficiency of the process.

Although not considered in our study, an important consideration in the viability of adsorbents for metal removal is their potential for reuse. There are various studies in the literature where solutions including $\mathrm{HCl}, \mathrm{HNO}_{3}, \mathrm{CH}_{3} \mathrm{COOH}, \mathrm{NaOH}$, EDTA and water are 
440 used to desorb metals from sorbents including those that present DTPA, EDTA and other

441 chelating agents at their surface (e.g. Huang et al., 2018; Alizadeh et al., 2018; Ma et al., 442 2017; Yuan et al., 2016; Zhao et al., 2015; Liu et al., 2009; Zhang et al., 2011; Yang and 443 Hodson, In press; Kaur et al., 2013; Venkateswarlu and Yoon, 2015, Zhang et al. 2016 (and 444 references therein)and thus we are confident that reuse of the DTPA functionalised magnetic 445 nanoparticles should be possible. Whilst that should be confirmed in laboratory studies, 446 more important requirements for future studies are further investigations using "real" rather 447 than synthetic test solutions and also the large scale application of this potential remediation 448 technology. Larger scale trials would address issues concerned with potential mixing of 449 nanoparticles in larger volumes of solution and also removal efficiencies of the nanoparticles 450 when, depending on the design of reactor vessels, the nanoparticles may be further from the 451 magnets required to collect the nanoparticles.

452 
454 Table 7. Metal partition coefficients $\left(\mathrm{K}_{\mathrm{d}} / \mathrm{L} \mathrm{kg}^{-1}\right)$ for $\mathrm{As}, \mathrm{Cd}, \mathrm{Cu}, \mathrm{Pb}$ and $\mathrm{Zn}$ extraction by

455 nanoparticles from different soil leachates. Values are means \pm standard error $(n=3)$.

456 Where solution concentrations were below detection limits these were set at the detection

457 limits for the purposes of calculation. For each element, values with an alphabetic

458 superscript in common are not significantly different $(p \geq 0.05)$ between soils as assessed by

459 analysis of variance (ANOVA) and Holm Sidak pair wise comparisons (As) or ANOVA on

460 ranks and Tukey tests $(\mathrm{Cd}, \mathrm{Cu}, \mathrm{Pb}, \mathrm{Zn}) .{ }^{<10 / h i}$ indicates significantly lower and >lo/hi significantly

461 higher values than the $\mathrm{K}_{d}$ determined on a single metal solution at the nearest $\mathrm{pH}$ below (lo)

462 or above (hi) that of the soil experiment, =lo/hi indicates no significant difference (Analysis of

463 variance and Holm-Sidak pair wise comparisons except for Avon and DGC Cu and Avon,

464 Barn, Graig and Wis Pb which were analysed by ANOVA on ranks and Tukey tests). Soil

465 names are as specified in the legend for Table 4.

\begin{tabular}{|c|c|c|c|c|c|}
\hline Soil & As & $\mathrm{Cd}$ & $\mathrm{Cu}$ & $\mathrm{Pb}$ & $\mathrm{Zn}$ \\
\hline Avon & $12900 \pm 0.00^{a}$ & $308 \pm 55.1^{a<10<h i}$ & $6750 \pm 1500^{\mathrm{ab}>10=h i}$ & $93500 \pm 72200^{a b=10=h i}$ & $227 \pm 50.5^{\text {ab<lo<hi }}$ \\
\hline Barn & & $1670 \pm 313^{\text {ab<lo<hi }}$ & & $4950 \pm 3086^{\mathrm{ab}=10=h i}$ & \\
\hline Cwm & & & & $19400 \pm 137^{\mathrm{ab}=10=\mathrm{hi}}$ & $6680 \pm 5230^{\mathrm{ab}=10=\mathrm{hi}}$ \\
\hline DGC & $1010 \pm 81.7^{b}$ & & $57100 \pm 27700^{\mathrm{a}=10>\mathrm{hi}}$ & & \\
\hline Graig & & $674 \pm 202^{\mathrm{ab}<l o<h i}$ & $4140 \pm 1390^{\mathrm{ab}=10=h \mathrm{~h}}$ & $233000 \pm 128000^{a=10=h i}$ & $511 \pm 236^{\mathrm{ab}<10<h i}$ \\
\hline Red & & & & & $10500 \pm 1470^{a>h i=10}$ \\
\hline Rook & $927 \pm 230^{\mathrm{bc}}$ & $16090 \pm 10090^{b=l o=h i}$ & & & $5420 \pm 2870^{\mathrm{ab}=10=\mathrm{hi}}$ \\
\hline \multicolumn{6}{|l|}{ Scun } \\
\hline Ship & & & & & $198 \pm 47.3^{\mathrm{b}<\mathrm{lo}<\mathrm{i}}$ \\
\hline Wis & $633 \pm 118^{c}$ & & $264 \pm 51.7^{\text {b<lo<hi }}$ & $1500 \pm 0^{\mathrm{b}=10=h i}$ & $852 \pm 778$ ab<lo<hi \\
\hline
\end{tabular}

466

467 


\section{Acknowledgements}

This work formed part of David Hughes' PhD work funded by the EPSRC. The EPSRC played no role in study design, in the collection, analysis and interpretation of data; in the writing of the report; and in the decision to submit the article for publication. Anne Dudley 473 (University of Reading, Department of Geography and Environmental Science) is thanked for her help with chemical analysis. We thank Professor Jacob de Boer and Dr Chan-Ping Yu for their assistance in the review process and two anonymous reviewers for their comments.

\section{References}

Afsar, A., Harwood, L.M., Hudson, M.J., Hodson, M.E., Shaw, E.J. (2014) Meocuproinefunctionalied silica-coated magnetic nanoparticles for extraction of copper (II) from aqueous solution. Chemical Communications 50 7477-7490.

Alexander, P.D., Alloway, B.J., Dourado, A.M. (2006) Genotypic variations in the accumulation of $\mathrm{Cd}, \mathrm{Cu}, \mathrm{Pb}$ and $\mathrm{Zn}$ exhibited by six commonly grown vegetables. Environmental Pollution, 144, 736-745.

Alizadeh, B., Delnavaz, M., Shakeri, A. (2018) removal of Cd(II) and phenol using novel cross-linked magnetic ETA/chitosan/ $\mathrm{TiO}_{2}$ nanocomposite. Carbohydrate Polymers 181 675-683.

Alloway, B.J. (1990) Cadmium. In: Heavy metals in soils. $1^{\text {st }}$ Ed.Blackie Academic and Professional: London pp 100 - 124.

Anderegg, G., Nageli, P., Muller, F., Schawarenbach, G. (1959) Komplexone .30. Diathylentriamin-pentaessigsaure (DTPA). Helvetica Chimica Acta 42 827-836.

Bao, S., Tang, L., Li, K, Ning, P., Peng, J., Guo, H., Zhu, T., Liu, Y. (2016) Highly selective removal of $\mathrm{Zn}(\mathrm{II})$ ion from hot-dip galvanizing pickling waste with amino-functionalized $\mathrm{Fe}_{3} \mathrm{O}_{4} @ \mathrm{SiO}_{2}$ magnetic nano-adsorbent. Journal of Colloid and Interface Science 462 235-242. 
Bell, P.F., James, B.R. and Chaney, R.L. (1991) Heavy metal extractability in long-term sewage-sl;udge and metal salt-amended soils. Journal of Environmental Quality 20 481-486.

Carvallaro, N. and McBride, M.B. (1984) Zinc and copper sorption and fixation by anacidsoil clay: effect of selective dissolutions. Soil Science Society of America Journal 481050 1054.

Chen, D., Shen, W., Wu, S., Chen, C., Luo, X., Guo, L. (2016) lon exchange induced removal of $\mathrm{Pb}(\mathrm{II})$ by MOF-derived magnetic inorganic sorbents, Nanoscale 87172 7179.

Chen, Z. Geng, Z. Zhang, Z., Ren, L., Tao, T., Yang, R., Guo, Z. (2014) Synthesis of magnetic $\mathrm{Fe}_{3} \mathrm{O}_{4} @ \mathrm{C}$ nanoparticles modified with $\mathrm{SO}_{3} \mathrm{H}$ and $\mathrm{COOH}$ groups for fast removal of $\mathrm{Pb}^{2+} \mathrm{Hg}^{2+}$, and $\mathrm{Cd}^{2+}$ ions, Eur. J. Inorg. Chem. 2014 3172-3177.

Chung, J. Chun, J. Woo, J., Lee, S.H., Lee, Y.J., Hong, S.W. (2012) Sorption of Pb(II) and $\mathrm{Cu}$ (II) onto multi-amine grafted mesoporous silica embedded with nano-magnetite: effects of steric factors, J. Hazard. Mater. 239-240 183-191.

Crane, R.B., Scott, T.B. (2012) Nanoscale zero-valent iron: future prospects for an emerging water treatment technology, J. Hazard. Mater. 211 112-125.

Dennis, I. (2005) The impact of historical metal mining on the river Swale catchment, North Yorkshire, UK. PhD Thesis. University of Aberystwyth.

Dines H.G., 1956. The metalliferous mining region of south-west England. HMSO, London

Dixit, S. and Hering, J.G. (2003) Comparison of arsenic (V) and arsenic (III) sorption onto iron oxide minerals: implications for arsenic mobility. Environ. Sci. Technol. 37 4182-4189.

Dojino, 2017. Dojino Molecular Technologies, Inc. https://www.dojindo.com/Images/Product\%20Photo/Chelate Table of Stability Const ants.pdf. Accessed $8^{\text {th }}$ May 2017. 
Figueira, P., Lopes, C.B., Daniel-da-Silva, A.L., Pereira, E., Duarte, A.C., Trindade, T. (2011) removal of mercury (II) by dithiocarbamate surface functionalized magnetic particles: Application to synthetic and natural spiked waters. Water Research 45 5773-5784.

Finzgar, N., Lestan, D. (2008) The two-phase leaching of Pb, Zn and Cd contaminated soil using EDTA and electrochemical treatment of the washing solution. Chemosphere 73 1484-1491.

Fryxell, G.E., Lin, Y., Fiskum, S., Birnbaum, J.C., Wu, H., Kemner, K., Kelly, S. (2005) Actinide sequestration using self-assembled monolayers on mesoporous supports. Environmental Science and Technology 39 1324-1331.

Fu, F.L., Dionysiou, D.D., Liu, H. (2014) The use of zero-valent iron for groundwater remediation and wastewater treatment: a review. Journal of Hazardous Materials 267 194-205.

Gill, R. and Ramsey, M.H. (1997) What a geochemical analysis means. In: Gill, R. (ed.) Modern Analytical Geochemistry: An Introduction to Quantitative Chemical Analysis Techniques for Earth, Environment and Materials Scientists (Longman Geochemistry Series). Pp $1-11$.

Hang, F., Lan, J., hao, Z., Yang, Y., Tan, R., Song, W. (2012) Removal of heavy metal ions from aqueous solution sing $\mathrm{Fe}_{3} \mathrm{O}_{4}-\mathrm{SiO}_{2}$-poly(1, 2-diaminobenzene) core-shell submicron particles. Journal Colloid and Interface Science 387 205-212.

Huang, Y., Wu, H., Shao, T., Zhao, X., Peng, H., Gong, Y., Wan, H. (2018) Enhanced copper adsorption by DTPA-chitosan/alginate composite beads: mechanism and application in simulated electroplating wastewater. Chemical Engineering Journal 339 322-333.

Hughes, S.J.S, 1981. The Cwmystwyth Mines: British mining no. 17. Monograph of the Northern Mine Research Society. 
Hughes, D.L., 2015. Remediation of metal contaminated soils and waters with engineered nanoparticles. University of Reading, unpublished thesis.

Hughes, D.L., Asfar, A., Harwood, L.M., Jiang, T., Laventine, D.M., Shaw, L.J., Hodson, M.E. (2017) Adsorption of $\mathrm{Pb}$ and $\mathrm{Zn}$ from binary metal solutions an in the presence of dissolved organic carbon by DTPA-functionalised, silica-coated magnetic nanoparticles. Chemosphere 183 519-527.

Kaur, M., Zhang, H., Martin, L., Todd, T., Qiang, Y. (2013) Conjugates of magnetic nanoparticle-actinide specific chelator for radioactive waste separation. Environmental Science and Technology 47 11942-11959

Kiekens, L., (1995) Zinc. In: Alloway B.J., (ed.) Heavy Metals in Soils: 2nd edition. Blackie Academic, London.

Kim, H.J., Leitch, M., Naknakom, B., Tilton, R.D., Lowry, G.V. (2017) Effect of emplaced $\mathrm{nZVI}$ mass and groundwater velocity on PCE dechlorination and hydrogen evolution in water-saturated sand. Journal Hazardous Materials 322 136-144.

Koehler, F.M., Rossier, M., Waelle, M., Athanassiou, E.K., Limbach, L.K., Grass, R.N., Günther, D., Stark, W.J. (2009) Magnetic EDTA: coupling heav metal chelators to metal nanomagnets for rapid removal of cadmium, lead and copper from contaminated water. Chemical Communications 4862-4864.

Lofrano, G., Carotenuto, M., Libralato, G., Domingos, R.F., Markus, A., Dini, L., Gautam, R.K., Baldantoni, D., Rossi, M., Sharma, S.K., Chattopadhyaya, M.C., Giugni, M., Meric, S. (2016) Polymer functionalised nanocomposites for metals removal from water and wasterwater: an overview. Water Research 92 22-37.

Lei, M., Zhang, Y., Khan, S., Qin, P., Liao, B., (2010). Pollution, fractionation and mobility of $\mathrm{Pb}, \mathrm{Cd}, \mathrm{Cu}$ and $\mathrm{Zn}$ in garden and paddy soils from a $\mathrm{Pb} / \mathrm{Zn}$ mining area. Environmental Monitoring and Assessment 168 215-222. 
570 Lestan, D., Luo, C.-L., Li, X.-D., 2008. The use of chelating agents in the remediation of metal-contaminated soils: A review. Environmental Pollution 153 3-13.

572

Li, X.-Q., Elliott, D.W., Zhang, W.-X. (2006) Zero-valent iron nanoparticles for abatement of environmental pollutants: Materials and engineering aspects. Critical Reviews in Solid State and Materials Science 31 111-122.

Liu, X., Hu, Q., Fang, Z., Zhang, X., Zhang, B. (2009) Magnetic chitosan nanocomposites: A useful recyclable tool for heavy metal ion removal. Langmuir $25,3-8$.

Liu, J.-F., Zhao, Z.-S., Jiang, G.-B. (2008) Coating $\mathrm{Fe}_{3} \mathrm{O}_{4}$ magnetic nanoparticles with humic acid for high efficient removal of heavy metals in water. Environmental Science and Technology 42 6949-6954.

Lo, I.M., Zhang, W.H., 2005. Study on the optimal conditions for the recovery of EDTA from soil washing effluents. Journal of Environmental Engineering 131 1507-1513.

Ma, J., Zhou, G., Chu, L., Liu, Y., Liu, C., Luo, S., Wei. Y. (2017) Efficient removal of heavy metal ions with an EDTA functionalised chitosan/polyacrylamide double network hydrogel. Sustainable Chemical Engineering 5 843-851.

McBride, M.B. (1994) Environmental Chemistry in soils. Oxford University Press, Oxford.

Nahmani, J., Hodson, M.E., Black, S., 2007. Effects of metals on life cycle parameters of the earthworm Eisenia fetida exposed to field-contaminated, metal-polluted soils. Environmental Pollution 149 44-58.

Oughton, D., Koin, P., Bleyl, S., Filip, J., Skácelová, P., Klaas, N., von der Kammer, F., Gondikas, A. (2017) Development and application of analytical methods for monitoring nanoparticles in reemdation: NanoRem 5. CL:AIRE, London, UK, pp 6.

Palumbo-Roe, B., Cave, M. R., Klinck, B.A., Wragg, J., Taylor, H., O'Donnell, K.E., Shaw, R.A., 2005. Bioaccessibility of arsenic in soils developed over Jurassic ironstones in eastern England. Environmental Geochemistry and Health, 27 121-130. 
595 Palumbo-Roe, B., Wragg, J., Cave, M., Wagner, D. (2013) Effect of weathering product assemblages on $\mathrm{Pb}$ bioaccessibility in mine waste: implications for risk management. Environmental Science and Pollution Research 20 7699-7710.

Pan, S., Li, J., Wan, G., Liu, C., Fan, W., Wang, L. (2016) Nanosized yolk-shell Fe3O4@Zr $(\mathrm{OH}) \times$ spheres for efficient removal of $\mathrm{Pb}(\mathrm{II})$ from aqueous solution. J. Hazardous Materials 309 1-9.

601

Papassiopi, N., Tambouris, S., Kontopoulos, A. (1999) Removal of Heavy Metals from

Partey, F., Norman, D., Ndur, S. and Nartey, R. (2008) Arsenic sorption onto laterite iron 605 concretions: temperature effect. J. Coloid. Interface Sci. 321 493-500.

Pociecha, M., Lestan, D., 2009. EDTA leaching of Cu contaminated soil using electrochemical treatment of the washing solution. Journal of Hazardous Materials,

Richardson, P.H.G., 1991. Mines of the Dartmoor and Tamar Valley After 1913. Devon Books, Tiverton.

Sahuquillo, A., Lopez-Sanchez, J.F., Rubio, R., Rauret, G., Thomas, RP., Davidson, C.M., Ure, A.M. (1999) Use of a certified reference material for extractable trace metals to assess sources of uncertainty in the BCR three stage sequential extraction procedure. Analytica Chimica Act 382 317-327.

Seguin, V., Gagnon, C., Courchesne, F. (2004) Changes in water extractable metals, pH and organic carbon concentrations at the soil-root interface of forested soils. Plant and Soil $2601-17$.

Shan, C., Ma, Z., Tong, M. (2015) Efficient removal of free and nitrilotriacetic acid complexed $\mathrm{Cd}(\mathrm{II})$ from water by poly(1-vinylimidazole)-grafted $\mathrm{Fe}_{3} \mathrm{O}_{4} @ \mathrm{SiO}_{2}$ magnetic nanoparticles. Journal of Hazardous Materials 299 479-485. 
621 Siegel, F.R., 2002. Environmental geochemistry of potentially toxic metals. Springer-Verlag, Berlin.

Sizmur, T., Watts, M.J., Brown, G.D., Palumbo-Roe, B., Hodson, M. E., 2011. Impact of gut passage and mucus secretion by the earthworm Lumbricus terrestris on mobility and speciation of arsenic in contaminated soil. Journal of Hazardous Materials 197 169175.

Varanasi, P., Fullana, A., Sidhu, S. (2007) Remediation of PCB contaminated soils using iron nano-particles. Chemosphere 66 1031-1038.

Venkateswarlu, S., Yoon, M., 2015. Core-Shell Ferromagnetic Nanorod Based on Amine Polymer Composite (Fe3O4@DAPF) for Fast Removal of Pb(II) from Aqueous Solutions. ACS Applied Materials \& Interfaces, 7, 25362-25372.Walsh, J.N. (1997) Inductively coupled plasma-atomic emission spectrometry (ICP-AES). In: Gill, R. (ed.) Modern Analytical Geochemistry: An Introduction to Quantitative Chemical Analysis Techniques for Earth, Environment and Materials Scientists (Longman Geochemistry Series). Pp 41-66.

Wang, X.S., Zhu, L., Lu, H.J. (2011) Surface chemical properties and adsorption of Cu (II) on nanoscale magnetite in aqueous solution. Desalination 276 154-160.

Wang, Y., Shi, L., Gao, L., Wei, Q., Cui, L., Hu, L., Yan, L., Du, B. (2015) The removal of lead ions from aqueous solution by using magnetic hydroxypropyl chitosan/oxidized multiwalled carbon nanotubes composites, Journal Colloid Interface Science 4517 14.

Weng, C.-H. (2004) Modeling Pb(II) adsorption onto sandy loam soil. Journal Colloid and Interface Science 272 262-270.

Yang, J.-K., Lee, S.-M., Davis, A. P., 2006. Effect of background electrolytes and pH on the adsorption of $\mathrm{Cu}$ (II) /EDTA onto $\mathrm{TiO}_{2}$. Journal of Colloid and Interface Science, 295, 14-20. 
Yang, T, Hodson, ME (In press) Investigating the potential of synthetic humic-like acid to remove metal ions from contaminated water. Science of the Total Environment

Yen, C.-H., Lin, H.-L., Chuung, J.-S., Yeh, H.-D. (2017) Adsorption of precious metals in water by dendrimer modified magnetic nanoparticles. Journal Hazardous Materials 322 215-222.

Yuan, C., Mingtong, C., Feng, L., Wang, J., Peng, Y. (2016) Efficient removal of $\mathrm{Cu}(\mathrm{II})$ using amino-functionalised superparamagnetic nanoparticles prepared via SI-ATRP. J Applied Polymer Science 42859.

Zeng, G., Pang, Y., Zeng, Z., Tang, L., Zhang, Y., Liu, Y., Zhang, J. , Lei, X., Li, Z., Xiong, Y., Xie, G. (2012) Removal and recovery of $\mathrm{Zn}^{2+}$ and $\mathrm{Pb}^{2+}$ by imine-functionalized magnetic nanoparticles with tunable selectivity. Langmuir 28 468-473.

Zhang, X., Lin, Y. -M., Chen, Z. -I. (2009) 2,4,6-Trinitrotoluene reduction kinetics in aqueous solution using nanoscale zero-valent iron. J. Hazardous Materials 165 923-927.

Zhang, F., Zhu, Z., Dong, Z., Cui, Z., Wang, H., Hu, W., Zhao, P., Wang, P., Wei, S., Li, R., Ma, J. (2011) Magnetically recoverable facile nanomaterials: Synthesis, characterisation and application in remediation of heavy metals. Microchemical Journal 98 328-333.

Zhang, H.J., McDowell, R.G., Martin, L.R., Qiang, Y. (2016) Selective Extraction of Heavy and Light Lanthanides from Aqueous Solution by Advanced Magnetic Nanosorbents. ACS Applied Materials and Interfaces 8 9523-9531.

Zhang, Y., Chu, C., Li, T., Xu, S., Liu, L., Ju, M., 2017. A water quality management strategy for regionally protected water through health risk assessment and spatial distribution of heavy metal pollution in 3 marine reserves. Science of The Total Environment, 599-600, 721-731.

Zhao, F.P., Repo, E., Sillanpaa, M., Meng, Y., Yin, D.L., Tang, W.Z. (2015) Green Synthesis of Magnetic EDTA- and/or DTPA-Cross-Linked Chitosan Adsorbents for Highly 

1281.

674 